\title{
Heavy Metal Analysis of Three Urban Rivers in Enugu, Nigeria
}

\author{
Chinedu Ifeanyi Atama ${ }^{1}$, Chioma Julieth Onovo², Chioma Janefrances Okeke ${ }^{1}$, \\ Ossai Nelson ${ }^{1}$ and Christopher Didigwu Nwani ${ }^{1 *}$
}

${ }^{1}$ Department of Zoology and Environmental Biology, University of Nigeria Nsukka, Nigeria.

${ }^{2}$ Department of Applied Biology and Biotechnology, Enugu State University of Science and

Technology, Nigeria.

\section{Authors' contributions}

This work was carried out in collaboration among all authors. Authors CIA and CJO jointly designed the study, performed the statistical analysis, wrote the protocol and wrote the first draft of the manuscript. Authors CJO and ON managed the analyses of the study. Author CDN managed the literature searches. All authors read and approved the final manuscript.

Article Information

\author{
DOI: $10.9734 / A R R B / 2020 / v 35 i 1030285$ \\ Editor(s): \\ (1) Dr. Paola Angelini, University of Perugia, Italy. \\ Reviewers: \\ (1) Moh. Awaludin Adam, University of Ibrahimy, Indonesia. \\ (2) Vardi Venkateswarlu, Vikrama Simhapuri University, India.
} Complete Peer review History: http://www.sdiarticle4.com/review-history/59030

Original Research Article

Received 10 May 2020

Accepted 16 July 2020

Published 30 September 2020

\begin{abstract}
The multiple industrial, domestic, agricultural, medical, and technological applications of heavy metals have led to their wide distribution in the environment, raising concerns over their potential effects on human health and the environment. This work focused on the determination of manganese, chromium, zinc, cadmium, arsenic, mercury, iron and lead concentrations in Abakpa, Iva Valley, and Transekulu Rivers which are close to residential areas in Enugu, Nigeria. The analysis were carried out using atomic absorption spectrometer (AAS). All the heavy metals tested in the three studied locations exceeded the different drinking water limits except zinc which was below secondary drinking water standard of $5.0 \mathrm{mg} / \mathrm{l}$. The levels of mercury and zinc were significantly higher in Abakpa River $\left(0.57 \pm 0.112\right.$ and $0.881 \pm 0.0015 \mathrm{mgl}^{-1}$ respectively). Iva valley showed higher levels of manganese, chromium, iron and arsenic compared to other rivers studied. The presence in these metals in the water sources are a great risk to humans and the environment.
\end{abstract}

Keywords: Heavy metals; rivers; Nigeria.

*Corresponding author: E-mail: chris.nwani@unn.edu.ng; 


\section{INTRODUCTION}

Water is a necessity and serves many purposes, which include drinking, irrigation, animal farming and recreation. It also serves as a habitat to numerous organisms. The availability of good quality water is therefore an indispensable feature for preventing diseases and improving quality of life. A wide range of contaminants are continuously introduced into the aquatic environment mainly due to increased industrialization, technological development, growing human population and exploitation of natural resources, agricultural and domestic wastes run-off. In Nigeria, the situation is no better by the activities of most industries and the populace towards waste disposal and management leading to increasing levels of contaminants in the environment [1]. Among these contaminants, heavy metals constitute one of the most dangerous groups because of their persistent nature, toxicity, tendency to accumulate in organisms and undergo food chain amplification and more still, they are nondegradable [2].

Heavy metals are generally defined as metals with relatively high densities, atomic weights, or atomic numbers. The criteria used, and whether metalloids are included, vary depending on the author and context. In metallurgy, for example, a heavy metal may be defined based on density, whereas in physics the distinguishing criterion might be an atomic number, while a chemist would likely be more concerned with chemical behavior. Heavy metals are more commonly defined as those having a specific density of more than $5 \mathrm{~g} / \mathrm{cm} 3$ [3]. The most common heavy metals in Nigeria are zinc, arsenic, cadmium, chromium, lead, mercury, manganese and vanadium.

The contamination of the aquatic ecosystem by heavy metals is a serious worldwide ecological problem and has far-reaching implications on both the aquatic and terrestrial organisms in the environment. Acute heavy metal intoxications in animals may lead to the damage of the central nervous system, the cardiovascular and gastro intestinal (GI) systems, kidneys, liver, endocrine glands, and bones [2]. According to FernandezLuqueno et al. [4], it may also cause damage to DNA, alterations on gene expression and other patho-physiological alterations. The large population around the metropolis with the associated activities such as washing, bathing and soil excavation could also contribute to the pollution of the rivers. Therefore, to reduce the accumulation of heavy metals, monitoring, and assessment of the heavy metal concentration has become a very critical area of study in recent years.

\section{MATERIALS AND METHODS}

\subsection{The Study Area}

Abakpa, Iva valley and Transekulu are towns located in Enugu metropolis. Abakpa is a large town and commercial settlement with an increasing number of residents and industrial companies. Iva valley is named after a valley in the area which bears the same name. The locality is also the site of Iva valley coal mine. Transekulu is also a residential area located in Enugu state.

\subsection{Sample Collection}

Samples were collected from the three different sites (Abakpa, Iva valley and Transekulu Rivers) located in Enugu State (Fig. 1) in $0.5 \mathrm{~L}$ sterilized for three months. Water samples were filtered and fixed in $15 \mathrm{M}$ (70\%) concentrated nitric acid $\left(\mathrm{HNO}_{3}\right)$ so as to stop microbial action and the adhereance of the metals on the walls of the plastic bottles. The bottles were sealed tightly after collection to avoid loss of samples.

\subsection{Physico-chemical Analysis of Water}

The physicochemical properties of the water samples such as colour, odour, $\mathrm{pH}$, total dissolved solute, turbidity, temperature, electrical conductivity, biological oxygen demand, were analyzed according to the procedures of APHA, AWWA, WPCF [5].

\subsection{Sample Digestion}

The digestion procedure was carried out by transferring a measured volume $(50 \mathrm{~mL})$ of a well mixed acid preserved water sample to a flask. Then $5 \mathrm{~mL}$ of concentrated $\mathrm{HNO}_{3}$ and a few boiling chips were added into the flask. The mixture was boiled and evaporated on a hot plate to the lowest volume possible (10 to $20 \mathrm{~mL}$ ). Heating and addition of conc. $\mathrm{HNO}_{3}$ as necessary was done until digestion was complete as shown by a light color clear solution. After this, the sample volumes were raised to $100 \mathrm{ml}$, filtered using Whatman No. 42 filter paper and analyzed for heavy metals. 


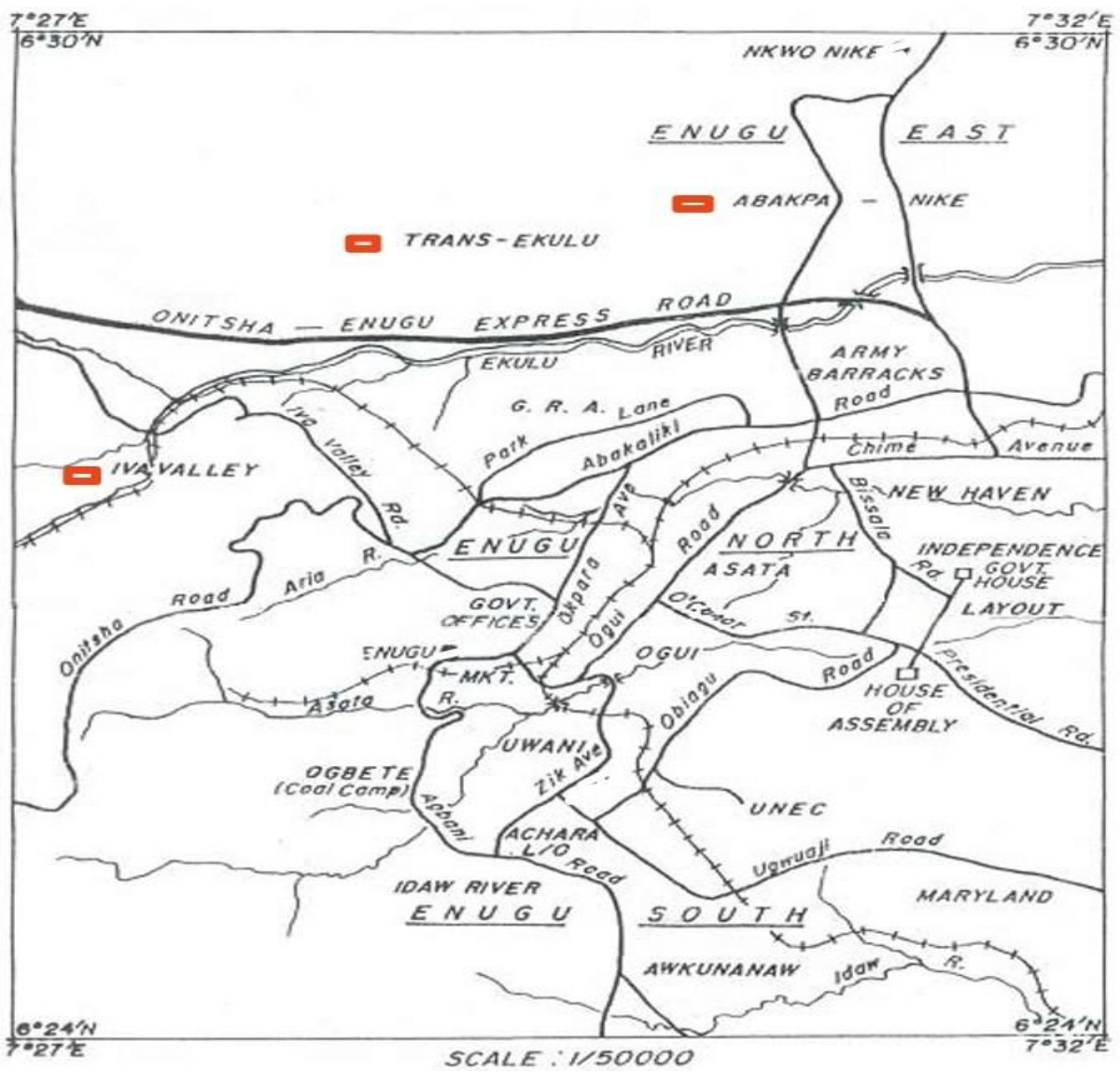

Fig. 1. Map of enugu urban area showing abakpa, iva valley and transekulu Source: Enete and Alabi [6]

\subsection{Metal Analysis of Water}

The metals were analyzed with the atomic absorption spectrometer (AAS -Perkin Elmer Model A Analyst and Varian AA-575) using calibration curves after the parameters (lamp alignment, wavelength and slit width adjustment and burner alignment) were optimized for maximum signal intensity and sensitivity of the instrument. The wavelength and slit width was selected and adjusted at the beginning of the analysis and was constant up to the end of the analysis. This condition was performed in the same way throughout the study.

\subsection{Statistical Analysis}

Data were analyzed using SPSS Version 20.0 (IBM Corp., Amonk, USA. Comparisons of the metals were done using Kruskal-Wallis $\mathrm{H}$-test. The values were represented as mean \pm standard error (SE). The level of significance was set at $p<0.05$.

\section{RESULTS AND DISCUSSION}

The physico-chemical properties of the water samples are presented in Tables 1 and 2. The $\mathrm{pH}$ range of 7.2-7.9 for samples from Abakpa, 7.3-8.0 for Iva Valley samples and 8.3-8.9 for Transekulu samples shows that the water samples are alkaline. Higher $\mathrm{pH}$, temperature and electrical conductivity were observed in Transekulu sample (Table 1). The concentrations of heavy metals in water samples from Abakpa, Iva valley and Transekulu was presented in Fig. 2. The concentration of manganese was highest in Iva valley with a value of $0.361 \pm 0.0235 \mathrm{mg} / \mathrm{l}$, followed closely by $0.346 \pm 0.015$ and $0.314 \pm 0.014$ in Transekulu and Abakpa respectively. Chromium was found to be highest in Iva valley sample at $0.879 \pm 0.116 \mathrm{mg} / \mathrm{l}$ and lowest in Abakpa at $0.655 \pm 0.03$. Mercury level in Abakpa sample was highest with a value of $0.57 \pm 0.112 \mathrm{mg} / \mathrm{l}$ and lowest in Transekulu with a value of $0.323 \pm 0.012$. Iva valley sample showed the highest concentration of lead at $0.381 \pm 0,019$. 
Zinc was found to be significantly higher in Abakpa with a value of $0.881 \pm 0.0015$. Iva valley sample showed a high arsenic level at $0.895 \pm 0.027$ followed by $0.883 \pm \mathrm{mg} / \mathrm{l}$ from that of Transekulu and $0.784 \pm 0.005$ from Abakpa sample. Cadmium was found to be highest in Iva valley sample with a value of $0.326 \pm 0.009 \mathrm{mg} / \mathrm{l}$ and iron also, with $0.959 \pm 0.052 \mathrm{mg} / \mathrm{l}$ concentration. This means that the highest levels of manganese, chromium, lead, arsenic, cadmium and iron were detected in Iva valley sample, some of which were followed closely by sample from Transekulu. This may be due to incessant discharge of domestic waste into the waterways by residents. The high values obtained from Iva valley sample may also be linked to the proximity of the abandoned coal mine. Mine waste from mining activities in the times past containing some of these metals may have been discharged and dispersed or washed by water into bodies of water. These metals have remained due to their ability to persist for long periods in the environment and may have bioaccumulated. Zinc and mercury were found to be highest in Abakpa sample. A possible reason for this is industrial effluents such as waste from cement and block industries close to the area, automobile washing and repair, improper refuse disposal which pollute the water. Compared to results obtained by Adaikpoh et al. [7] from river Ekulu sediments, results from this study are much higher than those obtained for the metals; chromium, cadmium, arsenic and lead but correspond with the range of manganese (0.256$0.389 \mathrm{mg} / \mathrm{kg}$ ). The results were reported to be due to the nearness of the coal mine from where the river takes its source and the geological setting of the area which favours intense gullying and fast accumulation of these toxic metals [7]. Also, Cobbina et al. [8] obtained lower levels of mercury, arsenic and zinc from water samples in Nangodi, northern Ghana but cadmium concentration (0.534) was however higher than that in this study. Our results agree with that of Ayenimo et al. [9] that reported increased accumulation of heavy metals in water samples from Warri River, Nigeria.

In all, the present study indicated that all the heavy metals tested in all three locations exceeded the different drinking water limits except zinc which was below secondary drinking water standard of $5.0 \mathrm{mg} / \mathrm{l}$ (Table 3 ). The results of the present study also indicate that Iva valley has higher levels of most of the heavy metals tested. This puts residents of the area more at risk especially since this water is consistently used for domestic purposes. Plants growing within the environment can accumulate the toxic metals. When put to agricultural use, the water containing these toxic elements is absorbed by vegetables which accumulate in the body when ingested. The health implication of the accumulation of these metals in the body may range from damage to the nervous system, lungs, kidneys, liver, endocrine glands, skin and other organs of the body. However, because they mostly present similar symptoms as common illnesses during acute toxicity, some of these heavy metals are usually not easily diagnosed till they get to highly toxic limits in the body. Lead, cadmium and mercury are highly toxic even at low concentrations.

Table 1. Physical properties of the water samples from abakpa, iva valley and transekulu

\begin{tabular}{llllllll}
\hline Sample & pH & TDS Mg/l & Temp & EC $(\mathrm{Ms} / \mathrm{m})$ & Colour & Turbidity & Odour \\
\hline Abakpa River & $7.2-7.9$ & $5.0-7.5$ & $25^{\circ} \mathrm{C}$ & $10.5-13$ & Cloudy & Not clear & Odorless \\
Iva valley & $7.3-8.0$ & $4.0-7.0$ & $24^{\circ} \mathrm{C}$ & $10.1-12$ & Not clear & Not clear & Odorless \\
Transekulu & $8.3-8.9$ & $6.0-7.5$ & $27^{\circ} \mathrm{C}$ & $11.1-13$ & Cloudy & Not clear & Offensive odor \\
\hline
\end{tabular}

Table 2. Chemical parameters of water samples from abakpa, iva valley and transekulu

\begin{tabular}{llll}
\hline Sample & Oxygen demand $(\mathbf{m g} / \mathbf{l})$ & $\begin{array}{l}\text { Chemical oxygen } \\
\text { demand(mg/l) }\end{array}$ & $\begin{array}{l}\text { Biochemical Oxygen } \\
\text { demand(mg/l) }\end{array}$ \\
\hline Abakpa river & $10.5-11.5$ & $12.5-13.5$ & $23-25$ \\
Iva valley & $12.6-13.0$ & $15.0-16.8$ & $27.6-29.8$ \\
Transekulu & $11.5-14.0$ & $14.0-15.5$ & $25.5-29.5$ \\
\hline
\end{tabular}




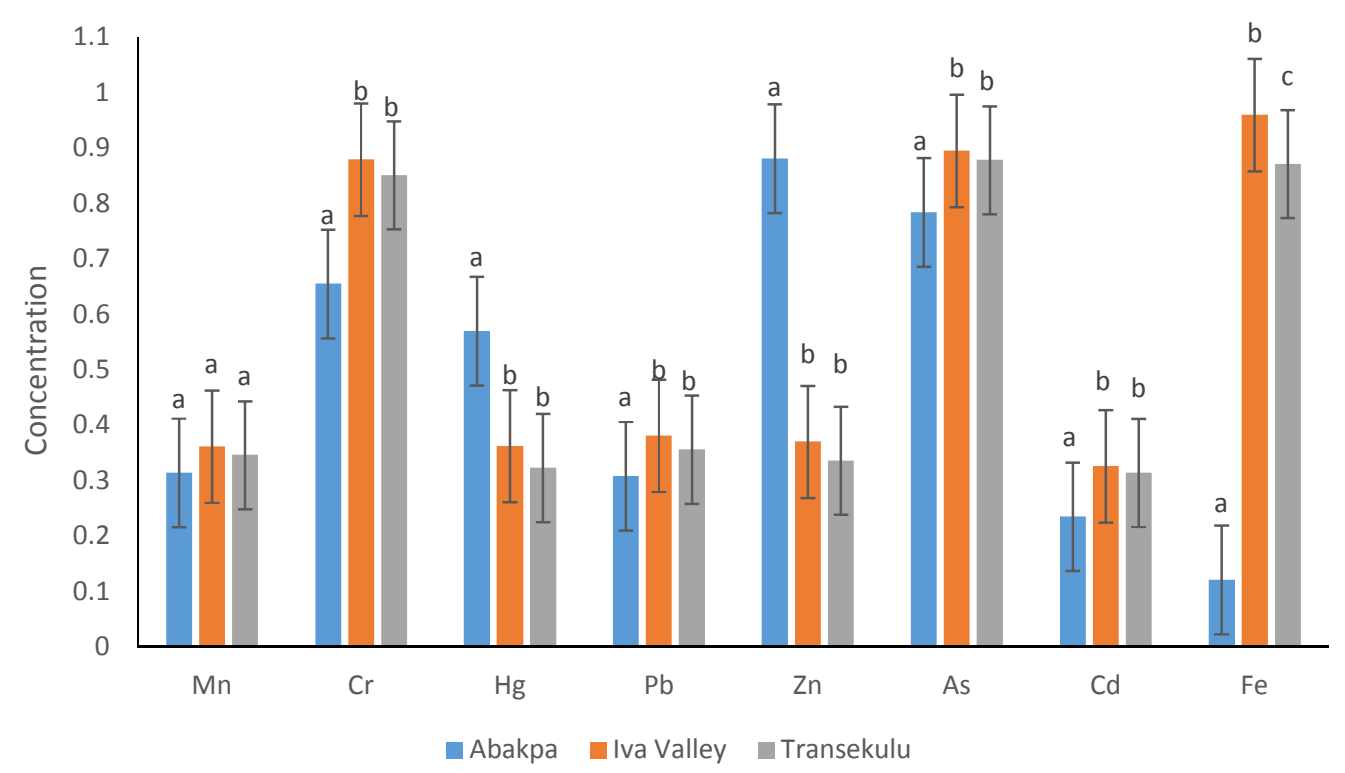

Fig. 2. Bar chart showing the concentrations of the detected metals in samples (mg/l) from abakpa, iva valley and transekulu

Table 3. Standard reference for water according to environmental protection agency I permissible limits for metals

\begin{tabular}{|c|c|c|c|c|}
\hline Metals & $\begin{array}{l}\text { Primary Drinking } \\
\text { Water Standard } \\
\text { (MCL) (Mg/l) }\end{array}$ & $\begin{array}{l}\text { Secondary Drinking } \\
\text { Water Standard (Mg/l) }\end{array}$ & $\begin{array}{l}\text { Livestock Water } \\
\text { Quality (Mg/l) }\end{array}$ & $\begin{array}{l}\text { Surface Water } \\
\text { Quality (Mg/l) }\end{array}$ \\
\hline $\mathrm{Al}$ & & $0.05-0.20$ & 5.0 & \\
\hline As & 0.05 & & 0.5 & 0.04 \\
\hline $\mathrm{Sb}$ & 0.006 & & & \\
\hline $\mathrm{Ba}$ & 2.0 & & & 1.0 \\
\hline $\mathrm{Be}$ & 0.004 & & & \\
\hline $\mathrm{Cd}$ & 0.005 & & 0.5 & 0.02 \\
\hline $\mathrm{Cr}$ & 0.1 & & 1.0 & 0.05 \\
\hline $\mathrm{Cu}$ & 1.3 & 1.0 & 0.5 & 1.0 \\
\hline $\mathrm{Fe}$ & & 0.3 & & \\
\hline $\mathrm{Pb}$ & 0.015 & & 0.05 & 0.10 \\
\hline $\mathrm{Mn}$ & & 0.05 & & \\
\hline $\mathrm{Hg}$ & 0.002 & & 0.01 & 0.002 \\
\hline $\mathrm{Ni}$ & & & 1.0 & \\
\hline $\mathrm{Se}$ & 0.05 & & 0.1 & 0.01 \\
\hline $\mathrm{Ag}$ & & 0.1 & & 0.05 \\
\hline $\mathrm{Ti}$ & 0.002 & & & \\
\hline $\mathrm{Zn}$ & & 5.0 & 25.0 & 5.0 \\
\hline
\end{tabular}

\section{CONCLUSION}

This present study focused on the determination of manganese, lead, chromium, mercury, arsenic and cadmium concentrations in water samples from Abakpa, Iva valley and Transekulu Rivers in
Enugu State, Nigeria. The results showed that the highest levels of most of the selected heavy metals in the selected areas were detected in the water samples collected from Iva valley. It is recommended that waste materials from the metropolis should be recycled and treated. They 
must not be disposed indiscriminately around the vicinity of the river to avoid possible pollution of the river. Further, agricultural activities around the river banks should be carried out with minimal use of agricultural fertilizers.

\section{ACKNOWLEDGEMENT}

The authors wish to acknowledge the support of the Head Department of Applied Biology and Biotechnology, Enugu State University of Science and Technology for the space provided for the experiment.

\section{COMPETING INTERESTS}

Authors have declared that no competing interests exist.

\section{REFERENCES}

1. Daniel ES, Musa JJ, Akos M, Yerima IY, Dada PO. Jibril I, Manta IH. Assessment of Heavy Metal Pollution in Some Nigerian Soils: A Review. $37^{\text {th }}$ Annual Conference and Annual General Meeting; Nigerian Institution of Agricultural Engineers. 2016;456-464.

2. Sankhla MS, Kumari M, Nandan M, Kumar $R$, Agrawal P. Heavy Metals Contamination in Water and their Hazardous Effect on Human Health-A Review. International Journal of Current Microbiology and Applied Sciences. 2016;5(10):759-766.

3. Järup L. Hazards of heavy metal contamination. British Medical Bulletin. 2003;68:167-182.
4. Fernández-Luqueño $F$, López-Valdez $F$, Gamero-Melo P, Luna-Suárez S, AguileraGonzález EN, Martínez Al, GarcíaGuillermo M, Hernández-Martínez G, Herrera-Mendoza R, Álvarez-Garza MA, Pérez-Velázquez IR. Heavy metal pollution in drinking water - a global risk for human health: A review. African Journal of Environmental Science and Technology. 2013;7(7): 567-584

5. APHA, AWWA, WPCF. Standard methods for theexamination of water and waste water 21st, $401 \mathrm{Ed}$. AmericanPublic Health Association, Washington, DC; 2005.

6. Enete I, Alabi MO. Observed urban heat characteristics in Enugu urban during the dry season. Global Journal of Human Social Science Geography and Environmental Geosciences. 2012;12(10): 75-80

7. Adaikpoh EO, Nwajei GE, Ogala JE. Heavy metal concentrations in coal and sediments from River Ekulu in Enugu, coal city of Nigeria. Journal of Applied Sciences and Environmental Management. 2005;9 (3):5-8.

8. Cobbina SJ, Duwiejah AB, Quansah R, Obiri S. Comparative assessment of heavy metals in drinking water sources in two small-scale mining communities in northern Ghana. International Journal of Environmental Research and Public Health. 2015;12:10620-10634.

9. Ayenimo JG, Adeeyinwo CE, Amoo IA. Heavy metal pollutants in Warri River, Nigeria. Journal of Sciences. 2015;27:4350.

(c) 2020 Atama et al.; This is an Open Access article distributed under the terms of the Creative Commons Attribution License (http://creativecommons.org/licenses/by/4.0), which permits unrestricted use, distribution, and reproduction in any medium, provided the original work is properly cited.

Peer-review history:

The peer review history for this paper can be accessed here: http://www.sdiarticle4.com/review-history/59030 